\title{
ANALYSIS OF HOUSEHOLD MEDICINE CHESTS: A SIGNIFICANT LEARNING EXPERIENCE FOR NURSING STUDENTS
}

\author{
Montserrat Solà ${ }^{1}$ Eva Garrido², Immaculada Úbeda ${ }^{3}$, Victoria Morin ${ }^{4}$, Raül Sancho ${ }^{5}$, Núria Fabrellas ${ }^{6}$
}

${ }^{1}$ Ph.D. Degree in Nursing. Professor of the Department of Public Health. School of Nursing. Universidad de Barcelona, Institut de
Recerca Biomèdica de Bellvitge (IDIBELL). Barcelona, Spain. E-mail: montsesolap@ub.edu
${ }^{2}$ Graduated in Market Research and Techniques. Professor of the Department of Public Health. School of Nursing. Universidad de
Barcelona, IDIBELL. Barcelona, Spain. E-mail: evagarrido@ub.edu
${ }^{3}$ Ph.D. Degree in Nursing. Professor Emeritus of the Department of Public Health, School of Nursing, Universidad de Barcelona.
Barcelona, Spain. E-mail: iubeda@ub.edu
${ }^{4}$ Ph.D. Degree in Nursing. Professor of the Department of Public Health, School of Nursing, Universidad de Barcelona. Barcelona,
Spain. E-mail: victoriamorinf@ub.edu
${ }^{5}$ Degree in Nursing. Professor of the Department of Public Health, School of Nursing, Universidad de Barcelona, IDIBELL. Barcelona,
Spain. E-mail: rsancho@ub.edu
${ }^{6}$ Ph.D. Degree in Nursing. Professor of the Department of Public Health, School of Nursing, Universidad de Barcelona, IDIBELL.
Barcelona, Spain. E-mail: nfabrellas@ub.edu

ABSTRACT: This is an observational, descriptive, cross-sectional study in which 214 nursing students from the University of Barcelona participated, in order to examine and assess the state and management of their household medicine chests. A semi-structured questionnaire specifically prepared for the study was used to collect data. The results showed that only $18.2 \%$ of the medicine chests examined contained all the recommended dressing materials and medicines. Inspection frequency was less than 12 months in $66.4 \%$ of the cases. A high percentage of the nursing students' homes stored medications in unsuitable locations and held on to them beyond their expiration dates or without their package. In contrast, knowledge about the use of the medications and the habit of recycling was better. Carrying out an analysis of their own medicine chest can help nursing students improve their competences in this area.

DESCRIPTORS: Drug storage. Home pharmacy. Students. Nursing.

\section{ANALISIS DE LOS BOTIQUINES DOMÉSTICOS: UNA EXPERIENCIA DE APRENDIZAJE SIGNIFICATIVA PARA LOS ESTUDIANTES DE ENFERMERÍA}

RESUMEN: Estudio observacional descriptivo y transversal en el que participaron 214 estudiantes de Enfermería de la Universidad de Barcelona con el objetivo de analizar y valorar el estado y la gestión de sus propios botiquines domésticos. Para la recogida de datos se utilizó un cuestionario semiestructurado de elaboración propia. Los resultados mostraron que solo el 18,2\% de los botiquines examinados tenían todos los materiales de curas y medicamentos recomendados. La periodicidad de revisión fue inferior a 12 meses en un $66,4 \%$ de los casos. Un elevado porcentaje de los hogares de los estudiantes de enfermería seguían guardando los medicamentos en lugares inadecuados y los almacenan caducados y fuera de su envase. En contraste, el conocimiento del uso de los medicamentos y el hábito de reciclaje fue mejor. Realizar un análisis sobre su propio botiquín podría ayudar a los estudiantes de enfermería a mejorar sus competencias sobre el tema. DESCRIPTORES: Almacenaje de medicamentos. Farmacia doméstica. Estudiantes. Enfermería.

\section{ANÁLISE DAS CAIXAS DE PRIMEIROS SOCORROS: ESTUDO REALIZADO EM ESTUDANTES DE ENFERMAGEM}

RESUMO: Estudo descritivo e transversal, no qual participaram 214 estudantes de enfermagem da Universidade de Barcelona com o objetivo de analisar e avaliar o estado e a gestão das caixas de primeiros socorros de suas casas. Um questionário semi-estruturado foi utilizado para coleta de dados. Os resultados mostram que apenas 18,2\% dos kits examinados tinham todos os materiais de curativos e medicamentos recomendados. A frequência de revisão é inferior a doze meses em 66,4 \% dos casos. Uma elevada porcentagem de residências familiares de estudantes de enfermagem continuvam mantendo os medicamentos armazenados em locais inadequados e vencidos, e fora de sua embalagem. Entretanto, se observou melhor conhecimento do uso dos medicamentos e do hábito de reciclagem. Realizar esta análise em sua própia caixa de primeiros socorros pode ajudar estudantes de enfermagem a melhorar suas habilidades sobre o tema.

DESCRITORES: Armazenagem de medicamentos. Farmácia doméstica. Estudantes. Enfermagem. 


\section{INTRODUCTION}

Self-care and people's independence are important elements to be considered from the perspective of a global concept of health. Within the scope of primary health care (PHC), the educational role that nurses play is decisive for promoting independence, co-responsibility and the safety of users.

Specifically in the home care context, special attention must be given to domestic hazard prevention measures, which includes proper management and consumption of medicine within the household environment, in response to different health situations.

One of the activities performed by PHC nurses is education for people's health in aspects related to self-medication, as well as compliance with drug prescriptions. ${ }^{1}$

The household or family medicine chest is where medications and first aid material is kept. Its purpose is to provide material for treating minor household accidents, in addition to having on hand the necessary medicines for treating certain symptoms, such as fever or pain, and also for storing regularly consumed medications.

Different professional health sciences associations and some health institutions have made certain recommendations on the content of household medicine chests, which, oddly enough, do not coincide with each other. When no one is responsible for its upkeep, medicine chests are liable to become storage places for previously prescribed medications..$^{2-3}$ Over time, most of the medicines expire or no longer have their packaging and insert, which contributes to using them incorrectly. ${ }^{4-6}$ For this reason, it is recommended that PHC nursing professionals make household visits and conduct educational programs on the proper use and management of the household medicine chest. ${ }^{7-8}$ Through such programs, nurses also promote ecological disposal of medications, to avoid containers and leftover medicine from being mixed with other household waste and, as often occurs, going to the garbage or down the drain, contaminating lakes and rivers. ${ }^{9}$

If people want to know about drug consumption, it is also useful to regularly inspect the medicine chest, ${ }^{10}$ given the high use of medications in our country, as reflected in a study presented at the Conference on Health Economics in Barcelona (2005), where it was noted that every patient surveyed took an average of 6.4 drugs per day. ${ }^{11}$

As far as their storage, a study conducted in Murcia found that $67.4 \%$ of the patients surveyed stored medicine in inappropriate places in the home, $45.6 \%$ felt that the drugs they kept were unnecessary and $16.4 \%$ never inspected their medicine chest. ${ }^{12}$ These aspects demonstrate improper use and management of medications.

In this regard, it would be beneficial to teach proper drug use and management in the educational stage of Health Sciences students. To achieve this, in the 2010-11 academic year, students from the School of Nursing of the University of Barcelona, during their period of community clinical practices, performed an analysis of their own household medicine chests, based on recommendations from the Departament de Salut de la Generalitat de Catalunya. ${ }^{13}$ The intent of this exercise, on the one hand, was for students to engage in a significant learning experience through reflecting on the task, ${ }^{14}$ by carrying it out in a real context, as clinical practices are, and on the other hand, learn about the content and way in which the household medicine chest is managed.

Of the studies conducted with Health Sciences students, those related to drug consumption are worth noting, ${ }^{15}$ but few studies have been found which examine how household medicine chests are managed in the homes of Health Sciences students. In two previously documented experiences, in one, the median of expired drugs was 19 in each medicine chest $^{16}$ and in the other, it was found that $9.5 \%$ of the medications were likewise expired. ${ }^{17}$

The primary objective of this study was to analyze and study the state and management of household medicine chests of nursing students from the University of Barcelona.

\section{MATERIAL AND METHODS}

This is an observational, descriptive, crosssectional study which involved the participation of third year students from the community practicum course of the School of Nursing of the University of Barcelona (UB). The data was collected between the months of April and June 2011.

The study population was comprised of the students taking the community practicum course during the study period $(n=250)$.

The inclusion criterion was that the student had access to the household medicine chest, and excluded those living in student residences or flats without access to this chest.

The study variables were: location of the medicine chest, access safety, contents, knowledge of the person responsible for use of its contents, inspection frequency and management of expired drugs. The 
following sociodemographic variables in reference to the person responsible for the household medicine chest were also included: age, gender, relationship to the student and education in the public health field, as well as the number and age of the persons living in the household.

To collect the data, a semi-structured questionnaire specifically prepared for the study was used, comprised of two parts: the first to collect information of a general and personal nature about the family and person responsible for the medicine chest; and the second part consisting of questions related to the study variables. The questions were for the most part closed-ended (dichotomous and multiple choice), with only one open-ended question about the medications contained in the medicine chest.

In February 2011, a test pilot was performed to assess whether the questions needed any adjustments; the experience indicated that it would be helpful to make some changes in the design of the questions, which then resulted in the final version.

After the students were informed of the study objectives and gave their consent, they received the questionnaire and instructions via a virtual platform for the course. After completing the questionnaire, 214 students returned it by email, representing an $85.6 \%$ response rate.

To describe the information obtained and according to the adjustment in the measurement scale for the variables, the analysis performed was univariate and descriptive in nature. Frequency tables and the multiple choice procedure were used for the multiple choice questions. The statistical software used to perform this analysis was PASW V18.

The study obtained financial assistance from the research committee of the School of Nursing of the University of Barcelona. In addition, to conduct this research, the recommendations contained in the good research practices code of the University of Barcelona were followed, such as: anonymity of the participants, confidentiality of the data recorded and ensuring students that there would be no adverse consequences for declining to be part of the study. An approval certificate was also received from the Bioethics Committee of the University of Barcelona (IRB00003099).

\section{RESULTS}

The place or room of the house where the medicine chest was most often kept was first the bathroom, followed by the kitchen, a bedroom and other locations. As far as the latter, the most cited was the dining room, with the remaining locations (in the minority) scattered among places such as the hallway, study, parking lot and pantry, among others (Table 1).

Table 1 - Rooms where dressing material and medications were stored $(n=214)$. Barcelona, Spain, 2011

\begin{tabular}{lll}
\hline Room & $\mathbf{n}$ & $\mathbf{\%}$ \\
\hline Kitchen & 88 & 31.9 \\
Bathroom & 110 & 39.9 \\
Bedroom & 32 & 11.6 \\
Other (dining room, hall, etc.) & 46 & 16.7 \\
\hline Total & $\mathbf{2 7 6}$ & $\mathbf{1 0 0}$ \\
\hline
\end{tabular}

The information provided about the medicine chest indicated that $61.2 \%$ of the medications and dressing materials were found in one single location in the household, and in $38.8 \%$ of the cases, it was divided between different places. Regarding the place of storage, the most common was a cupboard $(57.8 \%)$, followed by a drawer $(31 \%)$, a shelf $(8.7 \%)$ and lastly, other places (2.5\%), such as a plastic box or container which the families regarded as the medicine chest (Table 2).

Table 2 - Places where dressing material and medications were stored $(n=214)$. Barcelona, Spain, 2011

\begin{tabular}{lrr}
\hline Place & $\mathbf{n}$ & $\mathbf{\%}$ \\
\hline Drawer & 86 & 31 \\
Cupboard & 160 & 57.8 \\
Shelf & 24 & 8.7 \\
Other & 7 & 2.5 \\
\hline Total & $\mathbf{2 7 7}$ & $\mathbf{1 0 0}$ \\
\hline
\end{tabular}

In terms of free access to the medicine chest, in $73.5 \%$ of the cases only one responsible adult person could access the medications and dressing materials, whereas in the remaining $26.5 \%$ anyone could access them.

In the analysis of the medications found, there were: painkillers, anti-inflammatories, stomach-related drugs, antacids, creams, medicines for treating respiratory conditions and antibiotics. The results refer to the answers from 214 students, but since they tended to have more than one medication in their medicine chests, the data is more thoroughly examined after Table 3. 
Table 3 - Medications in household medicine chests $(n=214)$. Barcelona, Spain, 2011

\begin{tabular}{lrr}
\hline Medications & $\mathbf{n}$ & \% \\
\hline Painkillers & 202 & 94.4 \\
Anti-inflammatories & 196 & 91.6 \\
For respiratory conditions & 137 & 64 \\
Antibiotics & 101 & 47.2 \\
Cardiovascular & 76 & 35.5 \\
Antihistamines & 69 & 32.2 \\
Anxiolytics & 45 & 21 \\
Corticosteroids & 25 & 11.7 \\
Laxatives & 24 & 11.2 \\
Antipsychotics and antidepressants & 23 & 10.7 \\
Antianemics, iron & 20 & 9.3 \\
Eye drops & 20 & 9.3 \\
Oral antidiabetics & 18 & 8.4 \\
Vitamins and mineral supplements & 14 & 6.5 \\
Opiods & 12 & 5.6 \\
Contraceptives & 8 & 3.7 \\
Ear drops & 8 & 3.7 \\
Antineoplastics & 7 & 3.3 \\
Antithrombotics & 7 & 3.3 \\
Homeopathy & 7 & 3.3 \\
Insulin & 1 & 0.5 \\
\hline & & \\
\hline
\end{tabular}

In the medicine chests examined, there were also very high percentages (between $92 \%$ and $98 \%$ ) of gauze, adhesive bandages, alcohol, antiseptics, thermometers, analgesics, antipyretics and antiinflammatories. In slighter lower percentages (between $77 \%$ and $83 \%$ ), there was cotton, bandages and hydrogen peroxide. In lower percentages (from $49 \%$ to $68 \%$ ), scissors, tweezers, antihistamines and ointments for burns were found

It was also noted that only $18.2 \%$ of the medicine chests examined contained all the medications and dressing materials recommended by the Departament de Salut de la Generalitat de Catalunya. ${ }^{13}$

In turn, $52.8 \%$ of the students reported that all the medications in their medicine chest were inside their packages and $63.7 \%$ were past their expiration date.

As far as the person responsible for the medicine chest, $81.3 \%$ were women and $18.7 \%$ men. The average age of these individuals, who were also responsible to periodically inspect it, was 45 years with a standard deviation of 11.91. 69.9\% did not have any training in the field of health and 30.4\% did. Of those who did have such training, the most common were: nursing students (49.2\%), nursing assistants (12.3\%) and registered nurses (18.5\%).
In terms of the relationship between the student and the person responsible for the medicine chest, in $72.4 \%$ of the cases it was one of the parents (59.8\% mothers and $12.6 \%$ fathers), in $23.4 \%$ another kinship was marked (mostly the students themselves), in $2.3 \%$ it was the student's mate, in $1.4 \%$ a sister and in $0.5 \%$ the grandparents. Regarding the breakdown of the number of people living in the home and also looking at their ages, it was found that in $80 \%$ of the cases the students did not live with anyone from ages 1 to 15 ; in $41.1 \%$ of the cases, they lived with three people between the ages of 16 and 61 ; and in $90.2 \%$ they did not live with anyone over 65 years of age.

It is also worth noting that $90.6 \%$ of the people responsible for the medicine chest claimed to have adequate knowledge of the use of each medication.

In relation to the frequency with which the medicine chest is inspected, $66.4 \%$ did it within a period of 0 to 12 months, $13.6 \%$ within a period greater than one year and $20 \%$ checked it regularly.

In response to the question on what the home did with expired drugs, $80.3 \%$ said they took them to a recycling or specific pickup center and 19.7\% threw them out in the normal trash.

\section{DISCUSSION}

As far as the location of the medicine chests, the results of this study coincide with other papers where the kitchen and bathroom are the most used rooms in the house for storing them. ${ }^{12,18-20}$ Other studies also indicated these same locations, referring to them as inappropriate. ${ }^{6,18}$ According to the recommendation of health institutions, ${ }^{13,21}$ medications should be stored away from light, moisture and heat; for this reason, kitchens and bathrooms are not suitable places for storing medications.

On the other hand, a study was found which stated that in $37 \%$ of the household medicines were stored in more than one room. ${ }^{22}$ In our study, 27\% of the households also kept them in more than one room.

In this study, as in others, ${ }^{12,18-19}$ the places used as a medicine chest are primarily a drawer or cupboard.

In relation to safety, a risky location is considered to be one where medications are easily accessible to minors and people with dementia. In this study, in $26 \%$ of the homes surveyed, anyone could access the medicine chest. This percentage is slightly higher than one obtained in another study, which was $21 \%,{ }^{18}$ in striking contrast with another 
study in which the population at risk could access the medicine chest in only $3.4 \%$ of the homes. The reason for this difference could be due to the fact that in the latter study ${ }^{22}$ over one half of the homes had a person living there older than age 65 or younger than seven, whereas in this study, the population with this risk was less than $20 \%$. Furthermore, in both this study and the first one mentioned, ${ }^{18}$ the homes surveyed were those of the students themselves, which are characterized by their youth, suggesting that they lived with few minors or those suffering from dementia.

Regarding the type of medications found in the home, analgesics ranked first in $94.4 \%$ of the medicine chests examined, followed by anti-inflammatories in $91.6 \%$, and in third place, stomachrelated medications in $76.6 \%$. This data coincides with the findings of other researchers ${ }^{11-12,19,22}$ in which analgesics rank first. The results also agree with other studies where drugs for heartburn rank third. ${ }^{6,11}$ Some studies are also the same with respect to the presence of analgesics, ${ }^{2,7,15}$ although they differ from ours in terms of antibiotics, which in our study were in sixth place as compared to second in the other studies.

In relation to the mean for drugs found in the home, one study reports $19 .{ }^{16}$ Another paper, which investigated the medications found in the households of people included in the home social assistance program, mentioned that the mean for drugs was 15.3. ${ }^{11}$ According to a study conducted by the Integrated Packaging Management and Collection System (SIGRE), ${ }^{23}$ the household medicine chest contains from 11 to 12 drugs. In our study, unlike those above, the mean was 6.8. This is considered to be due to the youth of the sample.

With respect to dressing materials, a study ${ }^{22}$ similar to this one found high percentages of antiseptics, cotton and gauze in the household medicine chests.

As far as the presence of expired drugs, there is considerable disparity among the different studies that were analyzed. In this study, 33\% of the households had expired drugs, whereas other studies only reported between 11 and $12 \%{ }^{6,22}$ The highest percentage is from a study which cites $63 \%$, since it took two factors into account concurrently: unused or expired medications. ${ }^{19}$

The study conducted by SIGRE notes that $20 \%$ of citizens do not check the expiration date when they re-use a medication stored in the medicine chest. This fact could corroborate the presence of expired drugs in homes. ${ }^{23}$
In reference to the storage of drugs, in a study conducted in $\mathrm{Bilbao}^{22,}$ it was found that $55.5 \%$ of the households had some medicine outside it package, slightly higher than in this study, which was $47.2 \%$.

In terms of the profile of the person responsible for the medicine chest, no studies were found where this subject was directly addressed.

In our case, those responsible for the medicine chest were characterized, since more than half of them were connected to the health field, with the nursing students themselves being in charge of it. In other studies, despite not specifying who was responsible, they did mention that the people who participated in the study were mostly women, data which coincides with this study. ${ }^{11,22}$

As far as the knowledge that those responsible for the household medicine chest have regarding the use of the medications contained therein, an article reveals a high level of ignorance concerning their use, ${ }^{11}$ contrary to the findings of this study in which $90.6 \%$ of those responsible had adequate knowledge. This could be due to the fact that a high percentage of those responsible in this study were the nursing students themselves.

In relation to the frequency with which the medicine chest is inspected, in two papers it was found that $45.3 \%$ and $31 \%$ of the participants claimed to do it annually. These figures are lower than this study in which the maximum inspection frequency over the course of a year was $66.4 \%$. In these same two studies, $16.3 \%$ and $29 \%$ say they never inspect it, ${ }^{12,18}$ which is similar to this study where it was also found that $20 \%$ do not regularly inspect it.

One study reported that $26 \%$ of the homes surveyed threw drugs directly into the trash, ${ }^{18}$ whereas in this study $19.7 \%$ did so. Both these percentages are much lower than the findings of another study. ${ }^{12}$ The main difference between these studies was that the study population in the case of those who recycled the most was Health Sciences students. There is another study where recycling was related to co-payment for the medications. That author found that people who paid a certain portion recycled more $(23.1 \%)$, in contrast to $11.8 \%$ who received medications for free. ${ }^{19}$

The very heterogeneous nature of the study populations represented a limitation for comparison of results. At the same time, there may have been a bias as to the accuracy of the responses of students to some of the questions, with a tendency to give the correct answer instead of the real one. 


\section{CONCLUSIONS}

A high percentage of the nursing students' homes store medications in inappropriate locations, do not follow the recommendations of health institutions regarding the composition of the household medicine chest and have expired drugs and medications without their packages, which indicates that students do not apply all their drug management knowledge in everyday practice. In contrast, knowledge on the use of the medications is higher in their homes and inspection frequency and the habit of recycling medication is more entrenched. Carrying out an analysis of their own medicine chests can help nursing students integrate their knowledge and improve their competences in this area.

\section{REFERENCES}

1. Baos V. Estrategias para reducir los riesgos de la automedicación. Inf Ter Sist Nac Salut [online]. 2000 Jun [accessed 2015 Jul 11]; 24(6):147-52. Available from: http://www.msssi.gob.es/biblioPublic/ publicaciones/docs/200006-2.pdf

2. Kusturica MP, Sabo A, Tomic Z, Horvat O, Solak $Z$. Storage and disposal of unused medications: knowledge, behavior, and attitudes among Serbian people. Int J Clin Pharm [online]. 2012 Aug [accessed 2015 Jul 11]; 34(4):604-10. Available from: http:// www.ncbi.nlm.nih.gov/pubmed/22644600

3. Ocan M, Bbosa GS, Waako P, Oqwal-Okeng J, Obua C. Factors predicting home storage of medicines in Northern Uganda. BCM Public Health [online]. 2014 Jun [accessed 2015 Jul 11]; 26; 14:650. Available from: http://www.biomedcentral.com/1471-2458/14/650

4. Foroutan B, Foroutan R. Household storage of medicines and self-medication practices in southeast Islamic Republic of Iran. East Mediterr Health J [online]. 2014 Oct [accessed 2015 Jul 11]; 20(9):54753. Available from: http://www.ncbi.nlm.nih.gov/ pubmed/25343467

5. Wieczorkiewicz SM, Kassamali Z, Danziger LH. Behind closed doors: medication storage and disposal in the home. Ann Pharmacother [online]. 2013 Apr [accessed 2015 Jul 11]; 47(4):482-9. Available from: http://www.ncbi.nlm.nih.gov/pubmed/23535813

6. Vacas E, Castellà I, Sánchez M, Pujol A, Pallarés MC, Balagué M. Automedicación y ancianos. La realidad de un botiquín casero. Aten Primaria [online]. 2009 May [accessed 2015 Jul 11]; 41(5):269-74. Available from: http://www.elsevier.es/es-revista-atencionprimaria-27-articulo-automedicacion-ancianos-larealidad-un-13137733

7. Curry LC, Walker CC, Hogstel MO, Burns P. Teaching older adults to self-manage medications: Preventing adverse drugs reactions. J Gerontol Nurs [online]. 2005 Apr [accessed 2015 Jul 11];31(4):32-42. Available from: http:/ / web.b.ebscohost.com.sire.ub.edu/ehost/ pdfviewer/pdfviewer?sid=0bfdc977-54b1-4bd7-a001f24639ca97c7\%40sessionmgr110\&vid=1\&hid=110

8. Johnson M, Griffiths R, Piper M, Langdon R. Risk factors for an untoward medication event among elders in community-based nursing caseloads in Australia. Public Health Nurs [online]. 2005 JanFeb [accessed 2015 Jul 11]; 22(1):36-44. Available from: http://onlinelibrary.wiley.com.sire.ub.edu/ doi/10.1111/j.0737-1209.2005.22106.x/epdf

9. Muñoz I, Gómez MJ, Molina-Díaz A, Huijbregts MAJ, Fernández-Alba AR, García-Calvo E. Ranking potential impacts of priority and emerging pollutants in urban wastewater through life cycle impact assessment. Chemosphere [online]. $2008 \mathrm{Dec}$ [accessed 2015 Jul 11]; 74(1):37-44. Available from: http:/ / www. researchgate.net/publication/23414881

10. López S. Los 'botiquines domésticos' como método de estimar el uso de los medicamentos. Atención farmacéutica. 2001; 3(5):372-7.

11. Villafaina A, Salgado Rosa M, Iglesias EM. Resultados de la campaña de revisión de botiquines domésticos de personas incluidas en programas de asistencia social, por los farmacéuticos de atención primaria. In: ¿Dónde estamos 25 años después? XXV Jornadas de economía de la salud [online]. 2005 Jul 13-15 [accessed 2015 Jul 11]; Barcelona, España. Available from: http://www. aes.es/Jornadas25/comunicaciones/output/4.pdf

12. Hernández EB, Llamas JM, Orenes M, Salmerón J, Tomas E. Educación sanitaria: el botiquín casero. Seguim Farmacoter [online]. 2004 [accessed 2015 Jul 11]; 2 (1):46-9. Available from: http:/ / www.cipf-es. org/sft/vol-02/046-049.pdf

13. Departamento de Salud [página de Internet]. Barcelona (ES): Gencat; 2014 [updated 2011 May 11; accessed 2015 Jul 12]. Available from: http:// canalsalut.gencat. cat/ca/home_ciutadania/urgencies/farmaciola/

14. Medina JL, Castillo S. La enseñanza de la enfermería como una practica reflexiva. Texto Contexto Enferm [online]. 2006 Apr-Jun [accessed 2015 Jul 11]; 15(2):30311. Available from: http:// www.redalyc.org/articulo. oa?id=71415215

15. Herrera A, Prieto R, Veloza M, Riquelme G, De Sousa MPS, Mitchell C, et al. Policonsumo simultáneo de drogas en estudiantes de facultades de ciencias de la salud/ciencias médicas en siete universidades de cinco países de América Latina y un país del Caribe: implicaciones de género, legales y sociales. Texto Contexto Enferm [online]. 2012 [accessed 2015 Jul 11]; 21(Esp):17-24. Available from: http:// www.redalyc. org/articulo.oa?id=71423223002

16. Icart MT, Salas C, López C, Caja C, Roigé A. Los fármacos nos invaden: un estudio efectuado entre alumnos de Enfermería. Rev ROL Enferm. 1991 JulAgo; 155: 15-9.

17. Sanahuja MA, Salar L, Bisbal S. Revisión de los botiquines domésticos de alumnos de ciencias de 
la salud de la universidad CEU Cardenal Herrera. In: VII Jornadas de Farmacovigilancia [online]. 2008 May 29-30 [accessed 2015 Jul 11], Murcia, España. Available from: ttp:/ / www.murciasalud.es/ recursos/ficheros/132160-farmacovigilancia_DL.pdf

18. Arias JL, Ruiz MA, Gallardo V. El futuro farmacéutico y el botiquín familiar: Aprendiendo a realizar educación sanitaria. Ars Pharm [online]. 2009 Feb [accessed 2015 Jul 11]; 50(2):118-23. Available from: http:/ /farmacia.ugr.es/ars/ars_web/

19. Echave P, Pérez A, López JR, Dierssen T, Villa M, Raba S. Análisis de los botiquines caseros: ¿acumulan medicaciones nuestros pacientes? Med Gen. 2006 Nov; 90: 725-7.

20. González J, Otero A, Prieto J. Almacenamiento de antibióticos en los hogares españoles. Rev Esp Quimioter [online]. 2006 Sept [accessed 2015 Jul 11];
19(3):275-85. Available from: http://seq.es/seq/02143429/19/3/Original_J_Gonzalez.pdf

21. Col legi de farmacèutics de Barcelona [página de Internet]. Barcelona: COFB; 2014 [updated 2012 May 13; accessed 2013 Jun 20]. Available from: http://www.farmaceuticonline.com/ca/elmedicament/647-botiquin

22. Mintegui I, Álvarez I, Artola C, Causo C, Ibañez F, Muruguza I, et al. Características del botiquín familiar en el barrio de Rekaldeberri-Bilbao. Aten Primaria. 1995 Oct; 16(7):397-406.

23. SIGRE Medicamento y Medio Ambiente [Internet page]. Madrid: SIGRE; 2015 [updated 2015 Jun 6; accessed 2015 Jul 12]. Available from: http:// www.sigre.es/wp-content/uploads/2013/12/5. notaprensaEl20.pdf 